\title{
Correction: Renal Denervation Suppresses Atrial Fibrillation in a Model of Renal Impairment
}

The PLOS ONE Staff

Author Hong-yang Guo should be listed as the co-corresponding author. Hong-yang Guo may be contacted through email at guohongyang301@126.com.

\section{Reference}

1. Liang Z, Shi X-m, Liu L-f, Chen X-p, Shan Z-I, Lin K, et al. (2015) Renal Denervation Suppresses Atrial Fibrillation in a Model of Renal Impairment. PLoS ONE 10(4): e0124123. doi: 10.1371/journal.pone. 0124123 PMID: 25884946

\section{fopenaccess}

Citation: The PLOS ONE Staff (2015) Correction: Renal Denervation Suppresses Atrial Fibrillation in a Model of Renal Impairment. PLOS ONE 10(6): e0131366. doi:10.1371/journal.pone. 0131366

Published: June 18, 2015

Copyright: @ 2015 The PLOS ONE Staff. This is an open access article distributed under the terms of the Creative Commons Attribution License, which permits unrestricted use, distribution, and reproduction in any medium, provided the original author and source are credited. 